\title{
Gingival Metastasis from a Testicular Choriocarcinoma: An Unusual Case Report and Review of the Literature
}

\author{
Metástasis Gingival Desde un Coriocarcinoma Testicular: \\ Un Inusual Reporte de Caso y Revisión de la Literatura
}

Ignacio Velasco",;*; Leonardo Aguilar,;*; Juan Pastrian*; Cristina Mebus* \& Benjamín Martínez ${ }^{* * * *}$

\begin{abstract}
VELASCO, I.; AGUILAR, L.; PASTRIAN, J.; MEBUS, C. \& MARTÍNEZ, B. Gingival metastasis from a testicular choriocarcinoma: an unusual case report and review of the literature. Int. J. Morphol., 31(1):140-143, 2013.

SUMMARY: Metastasic tumours to the oral cavity are extremely rare lesions that represent $1 \%$ of all oral and maxillofacial malignancies. Most reported cases involve the jaw bones than the soft tissues. Metastasis to the oral soft tissues most prevalently affects the gingiva and alveolar mucosa. Gingival metastasis may have an unremarkable clinical appearance and they can be difficult to distinguish from more common hyperplasic or reactive lesions that appear to be benign entities, such as peripheral giant-cell granuloma, pyogenic granuloma and peripheral ossifying fibroma. We present an unusual case of a testicular choriocarcinoma metastasized to the maxillary gingiva mimicking a reactive lesion. In addition, we also present a literature review of previous reported cases and a brief discussion about the etiopathogeny of testicular germ cell tumors, and how these malignant cells can reach the gingival tissues.
\end{abstract}

KEY WORDS: Choriocarcinoma; Gingival metastasis; Oral metastasis; Testicular choriocarcinoma; Germ cell tumors.

\section{INTRODUCTION}

Metastasic tumors to the oral cavity are extremely rare lesions that represent $1 \%$ of all oral and maxillofacial malignancies (Hirshberg \& Buchner, 1995). Studies show that primary tumors which frequently produce metastasis to oral tissues are the lungs, breast, kidney, liver and prostate (Hirshberg et al., 2008). Most reported cases involve the jaw bones than the soft tissues and the vast majority of these lesions are located in the posterior region of the mandible. Oral metastases can follow two recognized patterns: metastasis to the jawbones, which may be associated with secondary extension into the adjacent oral soft tissue and metastasis that involves only the oral soft tissues without any evidence of bone involvement (Hirshberg et al., 2008). Metastasic lesions to the oral soft tissues and gingiva are the less frequent and only constitute about $0.1 \%$ of all malignant lesions in the maxillofacial region (Shen et al., 2009).

Metastasis to the oral soft tissues most prevalently affects the gingiva and alveolar mucosa, followed by the tongue and, less frequently, the tonsil, palate, lip, buccal mucosa, and floor of the mouth (Shen et al.). Gingival metastasis may have an unremarkable clinical appearance and they can be difficult to distinguish from more common hyperplasic or reactive lesions that appear to be benign entities, such as peripheral giant-cell granuloma, pyogenic granuloma and peripheral ossifying fibroma (Shen et al.).

The oral metastasis from a testicular cancer is even a more rare entity. Shen et al., in their review of metastatic tumours to the oral and maxillofacial region found that $0.9 \%$ of 765 well documented cases in the literature are from testicular malignancies with only three cases reported in the literature.

Testicular germ cell tumors (GCTs) are a heterogeneous group of tumours with diverse histopathology and clinical behavior. GCTs are generally malignant and represent $93 \%$ of all testicular neoplasms, they originate from the male gonad and are classified into two broad categories, namely seminoma and nonseminomatous germ cell tumor (NSGCT) (Ulbright, 2005). NSGCT comprise embryonal carcinoma, yolk sac tumor, immature or mature teratoma, choriocarcinoma and other rare trophoblastic tumors. Pure testicular choriocarcinoma (TC) is a rare germ cell neoplasm,

\footnotetext{
* Department of Oral and Maxillofacial Surgery. Hospital Del Salvador, Santiago, Chile.

** Department of Oral and Maxillofacial Surgery. Universidad de Los Andes, Santiago, Chile.

*** Department of Oral and Maxillofacial Pathology. Universidad Mayor, Santiago, Chile.
} 
accounting for less than $3 \%$ of all the testicular neoplasms. TC spreads rapidly and widely, and has the worst prognosis of all the GCTs (Ulbright).

We present an unusual case of a TC metastasized to the maxillary gingiva mimicking a reactive lesion. In addition, we also present a literature review of previous reported cases and a brief discussion about the etiopathogeny of GCTs, and how these malignant cells can reach the gingival tissues.

\section{CASE REPORT}

A 33-year-old hispanic male patient without significant medical history, consulted to the ENT department (Hospital del Salvador, Chile) due to a painless inflammation of the neck that was initially treated with anti-inflammatory drugs, but evolving into dysphagia and a weight loss of $6 \mathrm{~kg}$ in two months. Clinically, the neck mass was indurated to palpation and adherent to deep planes in the right sternocleidomastoid region measuring $2.5 \mathrm{~cm}$ in diameter. Blood tests, biochemical and thyroid functions - including triiodothyronine (T3) thyroxine (T4) - thyroid stimulating hormone (TSH), thyroglobulin and thyroid antibodies - were within normal ranges. The patient underwent an incisional biopsy. Histopathology-immunohistochemistry showed a great number of large multinucleated syncytiotrophoblastic cells and mediumsized cytotrophoblastic cells in a hemorrhagic and necrotic stroma. Immunohistochemistry results in intensely positive for cytokeratin of high and low molecular weight (AE1-AE3) and for b-sub-unit of human chorionic gonadotrophin (b-hCG) (Fig. 1). Serum tumor markers for bhCG > 200,000 mUI/ml (normal: $<5 \mathrm{mUI} / \mathrm{ml}$ ) and alpha fetoprotein (a-FP) $3.58 \mathrm{ng} / \mathrm{ml}$ (normal: $<11 \mathrm{ng} / \mathrm{ml}$ ) suggested the diagnosis of metastatic choriocarcinoma of the upper mediastinum or testicle.

Testicular ultrasound given to the patient reports a malignant tumor of the right testicle. A computerized axial tomography is then taken of the head, neck, thorax, abdomen and pelvis, with the conclusion of secondary implantation focus on the brain, neck, lungs, and retroperitoneum. The case was evaluated by the oncology committee to start brain radiation and chemotherapy with primary diagnosis of metastatic TC. Right orchidectomy was performed and biopsy of the surgical specimen confirmed primary pure TC. Palliative external brain radiotherapy to a dose of $30 \mathrm{~Gy}$ in 10 fractions was applied. In addition, two lines of chemotherapy: 4 cycles of BEP scheme (cisplatin, etoposide $36 \mathrm{mg}$ and $180 \mathrm{mg}$ respectively from day 1 to 5 , bleomycin $30 \mathrm{mg}$ days 2, 8 and 15) and 5 months later: 3 cycles of TIP scheme (placitaxel $460 \mathrm{mg}$ day 1 , cisplatin $46 \mathrm{mg}$ and

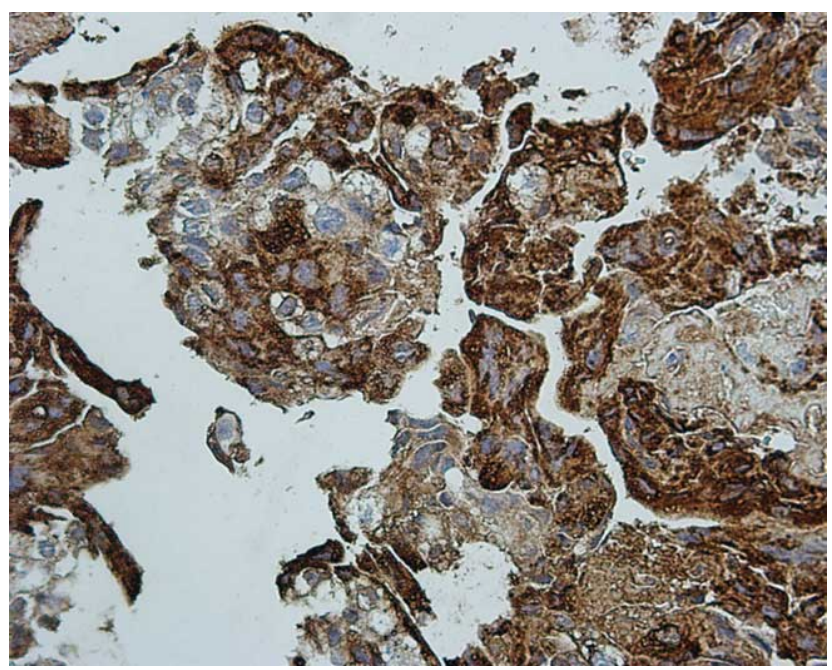

Fig.1. Histopathology of neck mass, with positive immunohistochemistry staining for b-hCG, original magnification $60 X$.

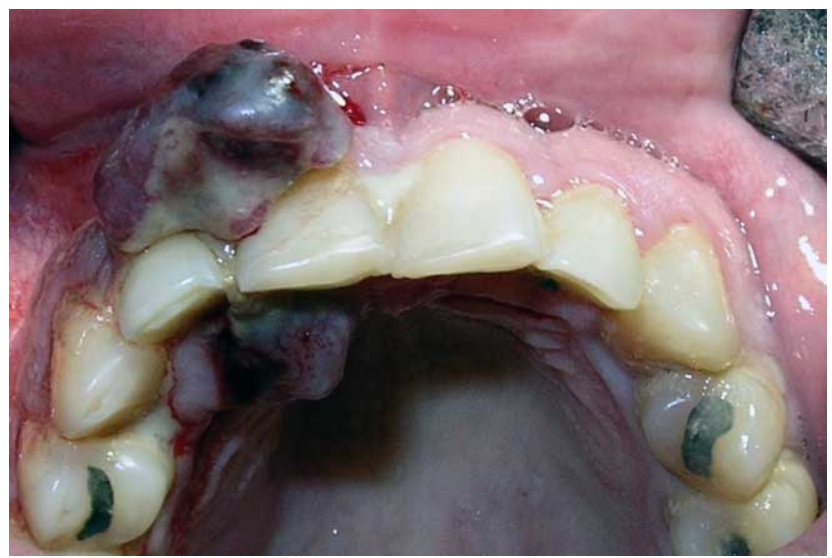

Fig.2. Clinical appearance of the lesion that compromises the buccal and palatal gingiva of right maxillary incisors.

ifosfamide $2.77 \mathrm{~g}$ day 2 to 5) due to persistence of multiple pulmonary and supraclavicular adenopathies.

One year later the patient is referred to the Oral and Maxillofacial Surgery department (Hospital del Salvador, Chile) due to a tumor on the maxillary gingiva with two weeks of evolution that caused discomfort and pain to the patient. Intraorally, there is a purple-colored, lobulated mass located in the anterior maxillary gingiva between right lateral and central incisors, measuring approximately $2 \times 2 \mathrm{~cm}$ (Fig. 2). Panorex does not evidence maxillary bone involvement. The biopsy of the lesion was planned with the hypothesis of a peripheral giant-cell granuloma or pyogenic granuloma. However, the histopathological study showed a great number of large multinucleated syncytiotrophoblastic cells and medium-sized cytotrophoblastic cells in a hemorrhagic and necrotic stroma ending up in metastasis of a pure TC (Fig. 3). The patient was followed during one week and does not 
showed any signs of infection. After two weeks of the biopsy the patient died due to the poor prognosis of his primary tumor and the advanced stage with multiple metastases.

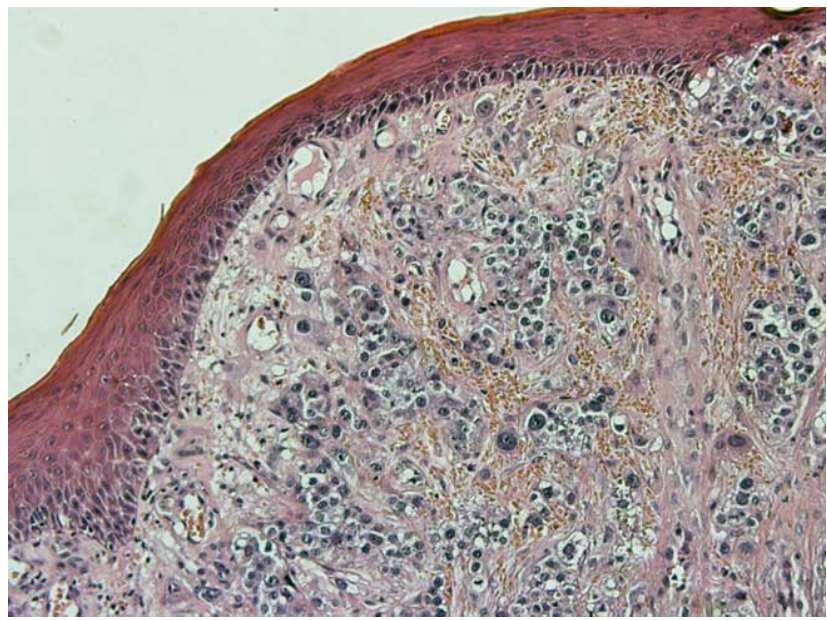

Fig. 3. Histopathology shows oral mucosa with proliferation of clear cytoplasm cells, dilated blood vessels and marked pleomorphism. Hematoxilin \& eosin stain, original magnification 120X.

\section{DISCUSSION}

Metastasic lesions to the oral cavity are rare being approximately $1 \%$ of oral malignancies. They involve the jaw bones more often than the oral soft tissues (Hirshberg et al., 2008). The gingiva is the most commonly affected soft tissue followed by the tongue. Köesem et al., (2004) review 121 cases of gingival metastasis were the most common metastasis is from the lungs (24.8\%), followed by the kidneys (12.4\%), liver $(9.9 \%)$, breasts $(9.9 \%)$, bones $(8.3 \%)$ and testis $(3.3 \%)$. The oral metastasis from a testicular cancer is a very rare entity. Shen et al., found that $0.9 \%$ of 765 well documented cases in the literature are from testicular malignancies.

Testicular GCTs are generally malignant and represent 93\% of all testicular neoplasms (Ulbright). Each type of GCT is considered to be the counterpart of each stage of normal embryo development. For example, seminoma is the neoplastic counterpart of the spermatocyte and represents the more undifferentiated type. On the other hand, syncytiotrophoblastic and cytotrophoblastic components of the placenta will give rise to pure choriocarcinomas that overproduce b-hCG (Ulbright).

Although, choriocarcinomas represent a more differentiated malignant counterpart, they are characterized by an aggressive biological behavior with tendency for haematogenous metastasis, possibly imitating the capacity of its normal counterpart (the placenta) to invade blood vessels. Pure TC is a rare germ cell neoplasm, accounting for less than $3 \%$ of all the testicular neoplasms and has the worst prognosis of all GCTs (Ulbright). The most common metastatic sites for $\mathrm{TC}$ are the lungs, liver and brain. Rare metastasis has been reported on the skin and oral soft tissues (Bhatia et al., 2007).

A computerized review of the accessible international literature focusing on the online database MEDLINE was conducted with the keywords: oral metastasis and choriocarcinoma. As a result we obtain three English-language articles (Nespeca \& Sass, 1980; Scolozzi et al., 2006; Bhatia et al.), we report one more case (Table I). The locations of all $\mathrm{TC}$ metastasis to oral region are in gingiva: three cases in maxillary gingiva and one case in mandibular gingiva. In our case was discarded the jaw bones involvement but in the rest of the cases is not specified. The oral metastasis was the first evidence of the disease in two cases, it presented as synchronous in one case and in the other case we knew the history of TC. The four cases presented metastasis in other tissues or organs.

The predilection of these malignant cells to reach oral soft tissue is not fully understood. In all cases reported of TC metastatic to oral cavity, the gingiva is affected. Some authors suggest the preference of metastasis to reach the attached gingiva in the presence of chronic gingivitis because the rich vascularity of the inflammatory process would allow trapping of tumour cells and thus being fertile site to spread most of the metastatic process (Auguste et al., 2007). Chronic inflammation is known to play a role in cancer initiation, promotion, and metastasis (Das Roy et al., 2012). However, the mechanism by which inflammation promotes metastasis is still unclear. Das Roy et al., have evaluated that chronic inflammation induced by autoimmune arthritis in mices may contribute to increased breast cancer-associated metastasis in bones and lungs. We believe that inflammatory periodontal

Table I. Literature review for testicular choriocarcinoma metastasic to oral cavity.

\begin{tabular}{lcclll}
\hline Author & Age & Race & Location & Extension & Metastasis \\
\hline Nespeca et al. (1980) & 77 & B & A max gingiva & Max central incisors & Brain, neck, lungs, kidney, gingiva \\
Scolozzi et al. (2006) & 36 & W & P L max gingiva & L max premolars & Brain, lungs, duodenum, gingiva \\
Bhatia et al. (2007) & 22 & W & L md gingiva & - & Skin, gingiva \\
Our report (2013) & 33 & W & A R $\quad$ max & R max incisors & Brain, neck, lungs, liver, retroperitoneum, gingiva \\
\hline
\end{tabular}

Abbreviations: B, black; W, white; A, anterior; max, maxillary; P, posterior; md, mandibular; L, left; R, right. 
diseases could be a risk factor for gingival metastasis, in cases with malignant neoplasms that spread through hematogenous route as the choriocarcinoma, breast and lung cancer. Hence, patients with this kind of malignant neoplasms require periodic oral examination and the early treatment of periodontal conditions.

Oral metastasis may be the first manifestation of widespread disease in $20-30 \%$ of cases and thus particular attention must be paid to gingival lesions associated with atypical clinical symptoms and/or signs (Shen et al.). The clinical presentation in our case was a gingival lesion associated with an inflammatory or reactive process such as peripheral giant-cell granuloma, pyogenic granuloma and peripheral ossifying fibroma (Hirshberg et al., 2008; Shen et $a l$.$) . It is clear that in many cases diagnosis can be difficult$ and requires an exhaustive and complete medical history, as well as a biopsy for histological diagnosis is fundamental in defining the nature of the lesion.

Finally, our case report reflects that metastasis to oral cavity is an indicator of an advanced stage with a low survival rate, because from the time it appears, the metastasis and the patient's death does not usually exceed a few months and less than $10 \%$ survive at 4 years after diagnosis (Hirshberg et al., 2008; Shen et al.). As in many cases, treatment is only palliative but removal of the lesion could be done if it causes pain or discomfort, and where the primary tumor is controlled.

VELASCO, I.; AGUILAR, L.; PASTRIAN, J.; MEBUS, C. \& MARTíNEZ, B. Metástasis gingival desde un coriocarcinoma testicular: Un inusual reporte de caso y revisión de la literatura. Int. J. Morphol., 31(1):140-143, 2013.

RESUMEN: Los tumores metastásicos a la cavidad bucal son lesiones extremadamente raras que representan el 1\% de todas las neoplasias malignas bucales y maxilofaciales. La mayoría de los casos reportados afectan más a los huesos maxilares que los tejidos blandos. Las metástasis a los tejidos blandos bucales involucran más prevalentemente a la encía y la mucosa alveolar. Las metástasis gingivales pueden tener un aspecto clínico no característico y suelen ser difíciles de distinguir de otras lesiones hiperplásicas o reactivas que parecen ser entidades benignas, tales como el granuloma periférico de células gigantes, el granuloma piogénico y el fibroma osificante periférico. Presentamos un inusual reporte de caso de un coriocarcinoma testicular metastásico a la encía maxilar simulando una lesión reactiva.Además, también se presenta una revisión de la literatura de los casos previamente publicados y una breve discusión acerca de la etiopatogenia de los tumores testiculares de células germinales, y cómo estas células malignas pueden llegar a los tejidos gingivales.

PALABRAS CLAVE: Coriocarcinoma; Metástasis gingival; Metástasis oral; Coriocarcinoma testicular; Tumores de células germinales.

\section{REFERENCES}

Auguste, P.; Fallavollita, L.; Wang, N.; Burnier, J.; Bikfalvi, A. \& Brodt, P. The host inflammatory response promotes liver metastasis by increasing tumor cell arrest and extravasation. Am. J. Pathol., 170(5):1781-92, 2007.

Bhatia, K.; Vaid, A. K.; Rawal, S. \& Patole, K. D. Pure choriocarcinoma of testis with rare gingival and skin metastases. Singapore Med. J., 48(3):e77-80, 2007.

Das Roy, L.; Pathangey, L. B.; Tinder, T. L.; Schettini, J. L.; Gruber, H. E. \& Mukherjee, P. Breast-cancer-associated metastasis is significantly increased in a model of autoimmune arthritis. Breast Cancer Res., 11(4):R56, 2009.

Hirshberg, A. \& Buchner, A. Metastatic Tumors to the oral region. An overview. Eur. J. Cancer B Oral Oncol., 6B86):355-60, 1995.

Hirshberg, A.; Shnaiderman-Shapiro, A.; Kaplan, I. \& Berger, R. Metastatic tumors to the oral cavity pathogenesis and analysis of 673 cases. Oral Oncol., 44(8):743-52, 2008.

Kösem, M.; Cankaya, H. \& Kaya, Z. Choriocarcinoma metastatic to mandibular gingiva: case report and review of metastatic gingival tumors. J. Otolaryngol., 33(5):310-4, 2004.
Nespeca, J. A. \& Sass, J. K. Choriocarcinoma metastatic to maxillary gingiva. J. Oral Surg., 38(7):534-7, 1980.

Scolozzi, P.; Marret, N.; Bouzourene, H.; Luthi, F.; Bauer, J.; Jaques, B.; et al. Mixed testicular germ cell tumor presenting as metastatic pure choriocarcinoma involving the maxillary gingiva. J. Oral Pathol. Med., 35(9):579-81, 2006.

Shen, M. L.; Kang, J.; Wen, Y. L.; Ying, W. M.; Yi, J.; Hua, C. G.; et al. Metastatic Tumors to the Oral and Maxillofacial Region: A Retrospective Study of 19 Cases in West China and Review of the Chinese and English Literature. J. Oral Maxillofac. Surg., 67(4):718-37, 2009.

Ulbright, T. M. Germ cell tumors of the gonads: a selective review emphasizing problems in differential diagnosis, newly appreciated, and controversial issues. Mod. Pathol., 18(Suppl. 2):61-79, 2005.

Dirección para correspondence:

Dr. Ignacio Velasco M.

Los Andes University, School of Dentistry

Av. San Carlos de Apoquindo 2200

Las Condes. Santiago, Zip: 7550000

CHILE

Email: iavelasco@miuandes.cl

Received: 14-06-2012

Accepted: 22-10-2012 